УДК 811.111:378.147.091.33-027.22:793.7

\title{
ГЕЙМІФІКАЦІЯ ЯК МЕТОД НАВЧАННЯ ЗДОБУВАЧІВ ВИЩОї ОСвІтИ АНГЛІЙСЬКОї МОВИ
}

\author{
Л. Д. Зеленська, К. В. Ковінько
}

\section{GAMIFICATION AS A METHOD OF TEACHING ENGLISH FOR STUDENTS OF HIGHER EDUCATIONAL ESTABLISHMENTS}

\section{Zelenska, K. Kovinko}

\begin{abstract}
Запровадження методу гейміфікації в ЗВО пов'язане з низкою питань, які зумовлені необхідністю якісної модернізації чинної системи вищої освіти. Однією 3 основних причин впровадження цього методу $\epsilon$ необхідність підвищення рівня володіння англійською мовою, мотивації та інтересу сучасного студента до навчання англійської мови. У статті подано огляд підходів до тлумачення та розробки методу гейміфікації зарубіжними вченими. Доведено, що поширення цього методу в зарубіжній освітній практиці дозволяє розв'язувати низку проблем, пов'язаних із поширенням елементів смарт-освіти у вищій школі, реалізацією принципів трудності й доступності навчання, індивідуального підходу, оптимізації навчального процесу, а також підвищенням рівня зацікавленості предметом, формуванням у студентів умінь працювати в команді тощо. Акцентується увага на висновках зарубіжних учених про те, що метод гейміфікації є не лише дієвим способом набуття знань, але й має потужні важелі для формування в студентів навичок вирішення проблем, організації співпраці та комунікації. У дослідженні висвітлено різновиди методу гейміфікації (групова та індивідуальна форми), а також представлено результати педагогічного експерименту, що мав на меті виявлення впливу названого методу на підвищення рівня володіння англійською мовою студентів 3ВО у процесі навчання англійської мови та зміну їхньої мотивації до вивчення цієї навчальної дисципліни в поза аудиторний час. До педагогічного експерименту було залучено 40 студентів першого року навчання, що мали приблизно однаковий рівень знань 3 англійської мови. Експеримент тривав протягом навчального року. Студентів було розподілено на дві групи: експериментальну (ЕГ - 20 осіб) та контрольну (КГ - 20 осіб). Студентам експериментальної групи були завантажені на мобільні телефони додатки Lingvaleo, English LioDuo, Lingvist, EnglishDom, Ewa, якими вони активно користувалися впродовж навчального року. Студенти контрольної групи працювали без використання пропонованих додатків. Результати контрольного етапу експерименту зафіксували суттєве зростання рівня успішності студентів ЕГ у порівнянні 3 контрольною. До того ж студенти ЕГ, віддаючи перевагу таким додаткам, як Lingvaleo; English LioDuo; EnglishDom у навчанні англійської мови, методом самооцінки фіксували підвищення рівня пізнавального інтересу до вивчення цієї дисципліни у ЗВО. Отже, результати проведеного дослідження підтвердили висновки зарубіжних учених про ефективність застосування методу гейміфікації в освітньому процесі вищої школи, зокрема у навчанні англійської мови.
\end{abstract}


Ключові слова: навчання, англійська мова, додатки до смартфонів, метод гейміфікації, мотивація, рівень володіння англійською мовою, студенти, ЗВО.

The introduction of the method of gamification at higher educational establishments is associated with several issues that are conditioned by the need for qualitative reorganization of the current education system. One of the main reasons for introducing this method is the need to increase the level of language skills, motivation, and interest of the modern student in learning English. The article gives an overview of approaches to the interpretation and development of the method of gamification of foreign scientists. It is proved that the spread of this method in foreign education practice allows solving several problems related to the spread of elements of smart education in higher education, the implementation of the principles of difficulty and access to education, an individual approach, the optimization of the educational process, as well as raising the level of interest in the subject, the formation of students' ability to work in a team, etc. Emphasis is drawn on the conclusions of foreign scientists that the method of gaming is not the only one way of acquiring knowledge, but also has powerful levels to form students' skills in problem-solving, organization of cooperation and communication. The study highlights the varieties of the gamification method (group and individual forms), as well as the results of the pedagogical experiment, which was aimed at revealing the influence of the mentioned method on increasing the level of skills of students in the language of instruction in the process of learning the English language and changing their motivation to study this discipline in free time. In the pedagogical experiment, it was involved 40 students of the first year of study, which had approximately the same level of English. The experiment lasted throughout the school year. Students were divided into two groups: experimental (EG - 20 people) and control (CG - 20 people). Students from the experimental group used Lingvaleo, English LioDuo, Lingvist, EnglishDom, and Ewa applications for mobile phones during the school year. Students of the control group didn't use the proposed applications. Results of the control phase of the experiment recorded a significant increase in the level of success of the students of EG compared with the CG. Besides, the students of the EG, preferring such applications as Lingvaleo; English LioDuo; EnglishDom in the teaching of English, using the self-assessment method, recorded an increase in the level of cognitive interest in studying this discipline at higher educational establishments. Consequently, the results of the study confirmed the findings of foreign scientists on the effectiveness of the application of the methodology of gamification in the educational process at high school, in particular in the teaching of English.

Keywords: English, teaching process, application for smartphones, method of gamification, motivation, the level of language skills, students, higher educational establishments, pedagogical experiment.

Постановка проблеми. Проєвропейський курс України вимагає від сучасного студента вільного володіння англійською мовою. Утім, класична система навчання іноземних мов в умовах інформаційного суспільства втрачає ефективність і потребує впровадження нових цікавих та дієвих методів, зокрема ігрових. Сьогодні у світі ігрові методи активно використовуються під час навчання іноземної мови не лише в практиці роботи з дітьми дошкільного та молодшого шкільного віку, а набувають поширення в організації освітнього процесу в ЗВО та навчанні дорослих. 
В умовах цифрового суспільства активізується такий метод ігрового навчання, як гейміфікація. 3 метою підвищення якості навчання студентів ЗВО англійської мови пропонується розглянути метод гейміфікації більш детально 3 наведенням конкретних прикладів. Цей метод навчання $\epsilon$ досить новим, лише $26 \%$ наукових публікацій стосовно його впровадження здобули практичне застосування в системі освіти (Seaborn \& Fels, 2015), а перші розробки цього методу побачили світ декілька років тому (Deterding et al, 2011). Утім, популярність методу гейміфікації стрімко зростає завдяки можливості вирішення завдань, що протягом останніх років поставали перед системою класичної освіти, як-от: упровадження електронних засобів навчання, розвиток креативності студентів, їхньої мобільності, підвищення мотивації до навчання англійської мови тощо. Гейміфікація в зарубіжній теорії й практиці характеризується як дієвий та захоплюючий метод навчання іноземної мови, зокрема англійської.

Аналіз основних досліджень і публікацій, в яких започатковано розв'язання даного завдання. Зарубіжні дослідники подають різні визначення гейміфікації. Габе Зіхерманн і Ліндер визначають гейміфікацію як процес використання ігрової механіки і мислення для того, щоб захопити аудиторію і вирішити поточні питання, що постають перед здобувачами освіти (Zichermann, Linder, 2010). Емі Джо Кім уважає, що гейміфікація - це використання ігрових технологій $з$ метою перетворення завдань на більш захоплюючі та цікаві (Kim, 2000). Карл Капп подає найбільш розгорнуте, на наш погляд, визначення гейміфікації. На його думку, це використання принципів ігрової механіки (набору дій та правил, що реалізовуються в процесі інтерактивної взаємодії гри та гравця), естетики і мислення для того, щоб залучити студентів до навчального процесу, підвищити їхню мотивацію, активізувати навчання і вирішити проблему (Карр, 2012). Загалом гейміфікацію можна визначити як застосування ігрових механік в неігрових ситуаціях для досягнення певної мети. Ігрова механіка - це саме те як відбувається процес гри та правила за якими це відбувається. Структура та динаміка гри (наприклад, кількість гравців, час, що присвячується грі) мають відповідати контенту. В практичному застосуванні гейміфікації велика увага приділяється емоційному стану студента, залученого до гри та його успіхам. Розподіл усього курсу на невеликі «квести» дозволяє керувати увагою учасників освітнього процесу, а також підвищує реальну мотивацію до вивчення, що було виявлено в процесі проведення нашого експерименту. 
До загальних принципів ігрових методів навчання, зокрема гейміфікації, дослідники відносять видимий статус гри, соціальну активність гравців, їх свободу вибору, свободу програшу та швидкий зворотній зв'язок між тими, хто бере участь у грі (Dicheva et al, 2015). Видимий статус інформує студентів про процес завершення завдання або ілюструє їхній прогрес під час оволодіння новими навичками при застосуванні геймінгу. Соціальне залучення включає в себе передбачувані потреби конкуренції між студентами, або навіть групами студентів, водночас може включати в себе як роботу в команді й можливості групового навчання (Mak, 2013), так і взаємодію та кооперацію під час занять у групі (Landers \& Callan, 2011). Свобода вибору передбачає, що студенти вільні у виборі завдання, яке вони хочуть виконувати. Наприклад, за Холманом, Агіларом та Фішманом (Holman, Aguilar, \& Fishman, 2013), студенти можуть обирати між написанням есе, веденням блогу, груповим чи особистим проектом, у той час як інші дослідники, зокрема Дешутер та Абель (DeShutter \& Abeele, 2014) пропонують завдання, що передбачають створення відео для Ютубу, розробку навчальної гри або написання академічного есе. Свобода програшу виявляється в тому сенсі, що студенти мають змогу другої спроби вирішення завдання без будь-яких штрафних санкцій. Швидкий зворотній зв'язок відносять до ігрового контексту, що дає студентам змогу миттєво отримати відгук про результати своєї роботи.

Рисою, що відрізняє гейміфікацію від інших методів навчання, заснованих на принципах гри, є застосування комп'ютерної та інших видів інтерактивної техніки, характерних для комп'ютерних ігор, 3 метою активізації пізнавальної діяльності студентів й більшої їх залученості до процесу навчання. Зважаючи на це, ігри такого характеру можуть бути масовими, розрахованими на значну кількість користувачів (MMORPGігри - англ. massively multiplayer online role-playing game), включати в себе віртуальну реальність, контент, створюваний користувачами. 32010 р. гейміфікація широко використовується як елемент побудови навчальних програм і курсів. Прикладом можуть слугувати Knewton Math Readiness (розроблений 2011 p. у США) - курс навчання математики iз застосуванням ігрових механік; Minecraft (вперше розроблений в 2009 р. шведським програмістом Маркусом Персоном i на сьогодні суттєво удосконалений) - навчання інженерно-будівельному мистецтву. У процесі навчання англійської мови метод гейміфікації також має потужні важелі, оскільки сучасний студент не бажає сприймати лише теоретичну або 
загально доступну інформацію. Водночас гейміфікація має надзвичайно дієвий потенціал щодо формування мотивів до навчання, покращення рівня навичків володіння англійською мовою, кооперації студентів, розвитку в них креативного мислення тощо.

Так, зарубіжні вчені довели позитивний вплив гейміфікації на мотивацію студентів (Alsawaeir, 2018; Bell, 2017; Bevins \& Howard, 2018; Dicheva, 2015; Faiella, 2015). Студенти опановували навчальні курси 3 використанням методу гейміфікації з більшим інтересом, аніж інші такі курси. До того ж у процесі використання цього методу мало місце підвищення якості умов та результатів навчання (Dicheva et al, 2015). Дослідники констатують, що саме застосування елементів гейміфікації сприяє перетворенню нецікавих завдань у захоплюючі (Faiella et al, 2015). Емоційні результати використання цього методу, як правило, зосереджуються на таких елементах підвищення рівня сприйняття та володіння англійською мовою, як мотивація, ставлення до предмету та задоволення від процесу навчання, про що свідчать проведені інтерв'ю та анкетування (Alsawaeir, 2018; Hamari et al, 2014). При цьому науковці наголошують, щоб краще зрозуміти ефективність впливу гейміфікації на мотивацію, дослідникам варто проводити довгострокові дослідження, або, щонайменше, визначати, які саме методи гейміфікації здатні стимулювати внутрішню мотивацію (Alsawaier, 2018).

Натомість використання методу гейміфікації не набуло суттєвого поширення ані у працях з дидактики вищої школи, ані в класичному вітчизняному освітньому просторі.

Однак введення ігрових елементів під час вивчення англійської мови це ще не є процес гейміфікації. Викладач має персоніфікувати ігровий контент, ураховуючи його чотири основні складники: взаємодію (широкий спектр технік, які забезпечують соціальну взаємодію між користувачами); динаміку (використання захоплюючого сценарію, який приваблював би користувачів та стимулював їхню відповідну реакцію в режимі реального часу); механіку (використання віртуальних винагород, статусів, балів, рівнів та інших елементів, характерних для ігрового процесу) й естетику (створення загальної ігрової атмосфери, яка сприяє емоційному захопленню) (Комарницька , 2016).

Метою статті є виявлення впливу методу гейміфікації на підвищення рівня успішності у процесі навчання англійської мови та підвищення інтересу здобувачів вищої освіти до її вивчення в поза аудиторний час. 
Виклад основного матеріалу. Перевага методу гейміфікації полягає насамперед у ціннісно-орієнтаційній можливості (функція, потенціал) гри: беручи участь у ділових іграх, студенти можуть інтеріоризувати цінності як загально-соціального плану, так і специфічні професійно i особистісно значущі цінності, що робить гру ефективним інструментом виховання. Іншою перевагою ігор в освіті вважається формування соціально-комунікативної компетентності, яка передбачає безпосередню взаємодію (вступ у контакт, вплив на партнера, переговори, інтерв'ю, спостереження тощо), мисленнєві процеси 3 приводу взаємодії (цілепокладання, планування, коригування, здійснення, аналіз, рефлексія), роботу над собою як суб'єктом взаємодії (саморегуляція). Отже, використання ігрових методів забезпечує діяльнісний підхід в освіті. Провідними напрямами гейміфікації освіти можна вважати освітні ігри i застосування ігрових технік і методик (ігрової моделі, ігрового кодексу, ігрового матеріалу) з освітньою метою (Ткаченко, 2015).

У нашому дослідженні ігрові методи навчання англійської мови були розподілені на дві категорії: групові та індивідуальні.

До індивідуальних ігрових методів віднесено способи організації навчання студентів в індивідуальному навчальному режимі 3 використанням додатків (англ. арs) для смартфонів для навчання англійської мови. Під час проведення педагогічного експерименту було використано 5 різних додатків, проаналізовано їх вплив на рівень навчальних досягнень студентів, виявлено найбільш ефективні додатки для навчання англійської мови.

Для цього було використано такі додатки для смартфонів:

Lingvaleo - характерною особливістю цього додатку є, по-перше, персоналізація (програма навчання формується 3 урахуванням рівня володіння англійською мовою, цільової спрямованості та інтересів студентів), по-друге, значний вибір безкоштовного контенту, сучасних методик, що спрямовані на вивчення в основному теоретичних підвалин англійської мови;

English LioDuo - поєднує зображення та звук, має близько 80 тематичних уроків різної спрямованості, американську та британську транскрипції на вибір, підбір слів (vocabulary) за різними значеннями $\mathrm{i}$ вживаністю (складні слова, відібрані, застарілі, нові (містить статистичні дані щодо вживання у мові кожного окремого слова)); 
Lingvist - розумний додаток, яким передбачено аналіз способу вивчення англійської мови та можливості врахування особистих запитів студентів; він містить різні тематичні напрями, режим розпізнавання мови та відстеження особистих успіхів у навчанні;

EnglishDom - додаток, спрямований на засвоєння лексики англійської мови та розширення словникового запасу: має 4 типи вправ для запам'ятовування слів (вибір правильного варіанту перекладу, аудіювання, складання слів з окремих літер, друкування слів). Додаток також добирає графічні зображення для полегшення запам'ятовування за принципом асоціативного мислення, до кожного слова подається транскрипція, переклад та можливість прослуховування правильної вимови; окрім цього, додаток містить «контроль прогресу», що дозволяє адекватно оцінювати успішність студента у вивченні англійської мови; додаток

$E w a$ - надає широкий спектр можливостей для опанування англійської мови із залученням методів на вибір: читання книг, прослуховування улюбленої музики, перегляд фільмів та відео кліпів; цей додаток персоналізований, відтак студент має змогу обирати рівень тренувань, що відповідає його навчальним можливостям і ступеню підготовленості.

Таким чином, у процесі використання названих додатків для смартфонів студенти набували можливості самостійно розширювати словниковий запас, удосконалювати граматичні навички, розуміння прочитаного або почутого тощо. Водночас, навчання англійської мови в такий спосіб знижувало емоційну напругу, викликало зацікавлення й підвищувало пізнавальний інтерес.

До педагогічного експерименту було залучено 40 студентів першого року навчання, які мали приблизно однаковий рівень володіння англійською мовою. Експеримент тривав протягом навчального року. Студентів було розподілено на дві групи: експериментальну (ЕГ - 20 осіб) та контрольну (КГ - 20 осіб). Студентам експериментальної групи на початку навчального року було запропоновано використовувати додатки для смартфону у поза навчальний час, зокрема під час виконання завдань для самостійної роботи 3 метою поліпшення навичок володіння англійською мовою. Для цього їм були завантажені на мобільні телефони перелічені вище додатки, якими вони активно користувалися впродовж навчального року. Студенти контрольної групи працювали без використання пропонованих додатків. Мета дослідження полягала у 
вивченні дієвості використання додатків для смартфонів щодо підвищення рівня знань та вмінь студентів з англійської мови. Для оцінювання рівня навчальних досягнень студентів експериментальної і контрольної груп 3 англійської мови на початок i кінець експерименту було обрано контрольну роботу. Рівень навичок володіння англійською мовою студентів оцінювали за такою шкалою: 100-90 балів (відмінний рівень), 8289 балів (хороший рівень), 74-82 (середній рівень), 60-73 балів (задовільний рівень). Результати дослідження відображено на діаграмі рисунку 1.

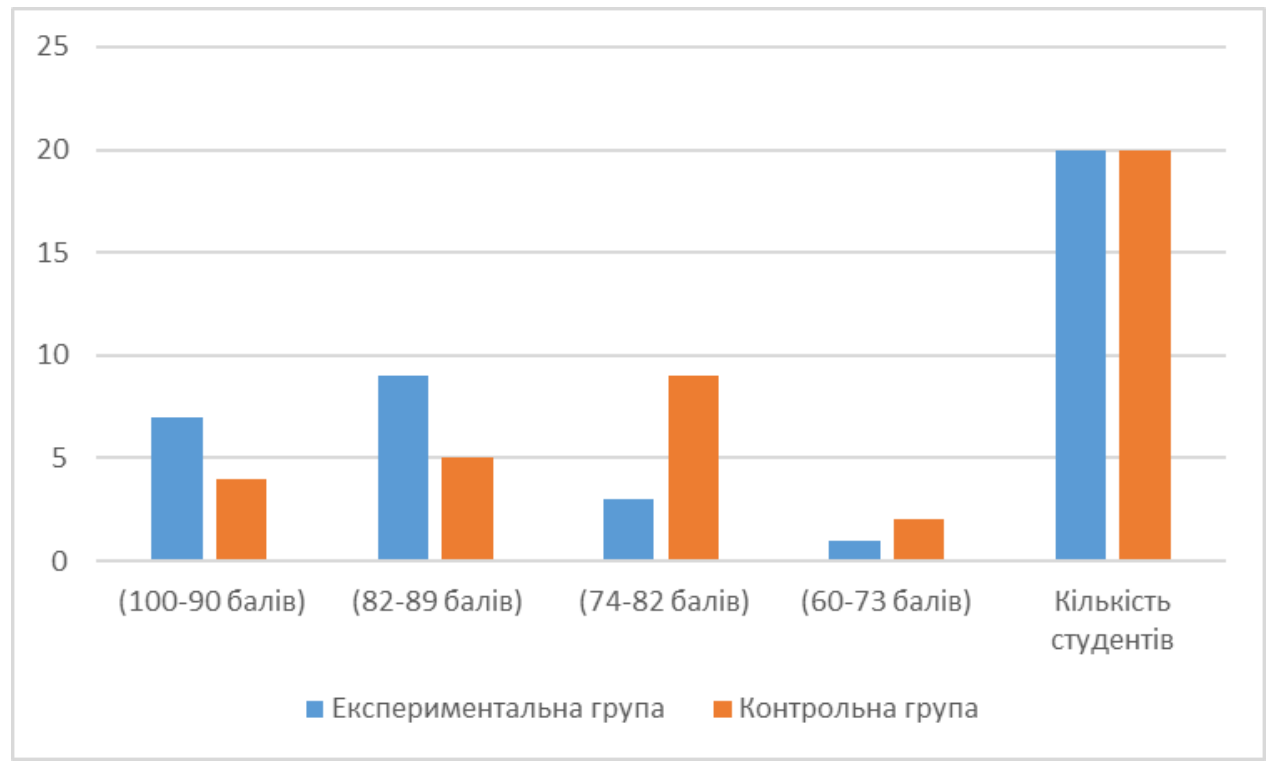

\section{Рис. 1. Результати дослідження рівня навчальних досягнень студентів з англійської мови по завершенні експерименту}

Таким чином, результати експериментальної роботи, представлені на рис. 1, свідчать, що студенти експериментальної групи продемонстрували рівень володіння англійською мовою вищий, ніж студенти контрольної групи. Це свідчить про дієвість використання мобільних додатків як однієї зі складових методу гейміфікації у процесі навчання студентів англійської мови. Зокрема використання додатків дозволяє більш вільно та самостійно покращувати вміння та навички володіння іноземною мовою в поза аудиторний час.

Друга частина експерименту мала на меті виявлення впливу методу гейміфікації 3 використанням додатків для смартфону не лише на підвищення рівня володіння студентами англійською мовою, але й зміну їхньої мотивації до вивчення цієї навчальної дисципліни у ЗВО. Оскільки 
використання додатків дає можливість вільно вивчати мову в будь-яких зручний час, а також підвищує інтерес до вивчення завдяки яскравому та інтерактивному контенту. По завершенні експерименту студентам було запропоновано взяти участь в опитуванні й методом самооцінки визначити вплив використаних додатків на пізнавальний інтерес до вивчення англійської мови за 10 бальною шкалою (10 - найвищий бал, 0 найнижчий). При цьому брали до уваги результативність самостійної роботи за критеріями впливу на: збільшення обсягу словникового запасу, навички правильної вимови, знання і дотримання правил граматики.

Результати проведеного опитування виявилися такими: додаток Lingvaleo отримав середню оцінку -8 балів; English LioDuo - 8 балів; Lingvist - 7 балів; EnglishDom - 8 балів; Ewa - 5 балів. Отримані дані проілюстровано на рис. 2.

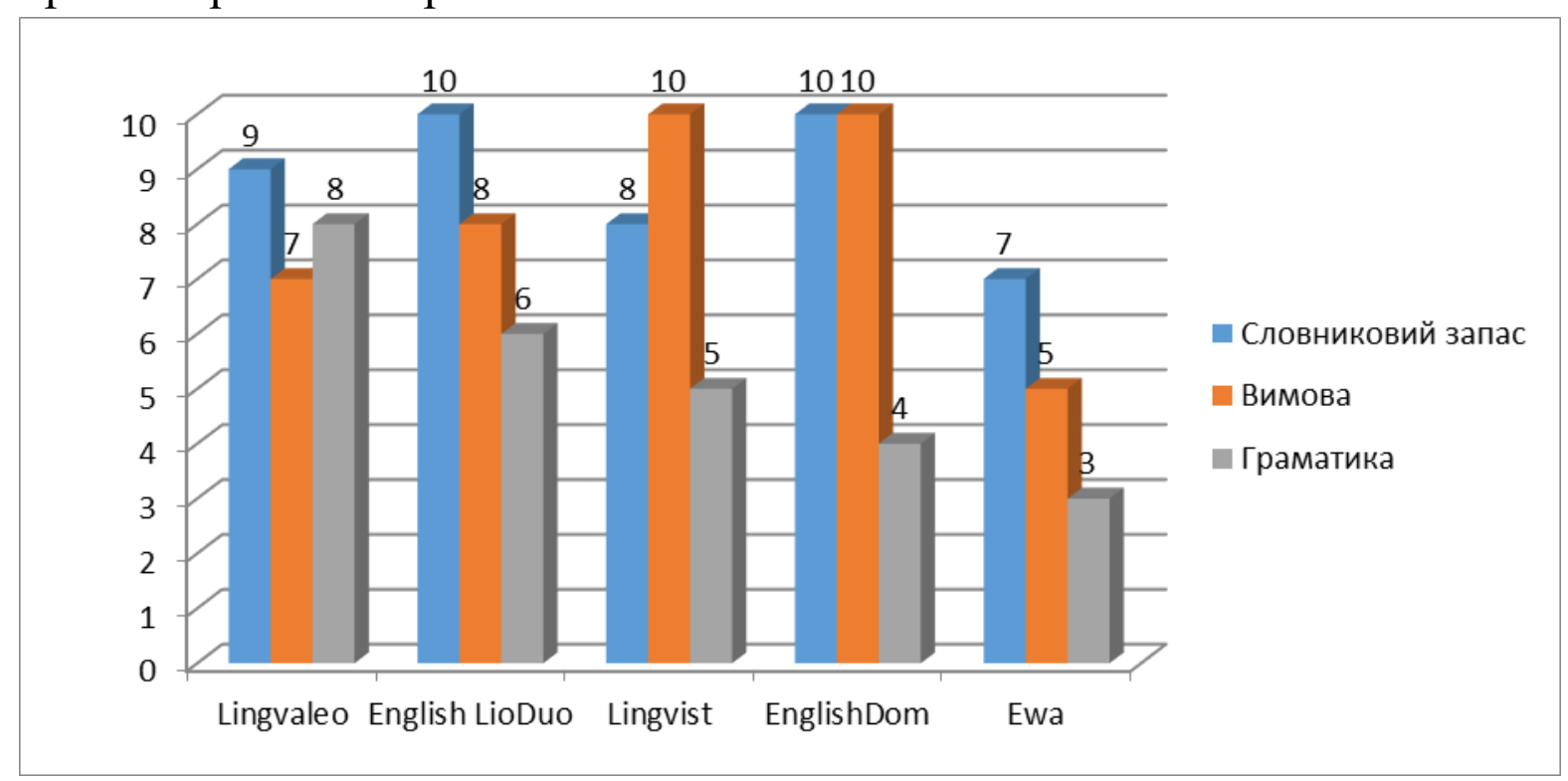

Рис. 2. Результати опитування студентів щодо ефективності використання додатків до смартфонів для підвищення пізнавального інтересу до навчання англійської мови у 3 ВО

Таким чином, за оцінкою студентів ЕГ, найбільш ефективним додатком для смартфонів, що дозволяє не лише підвищити рівень знань 3 англійської мови, але й стимулює пізнавальний інтерес до іiі вивчення через створення ігрового контенту, є додаток EnglishDom.

Результати проведеного дослідження засвідчують той факт, що метод гейміфікації як індивідуальної форми навчання, позитивно впливає на підвищення рівня вмінь володіння іноземною мовою та вмотивованості студентів до навчання англійської мови, суттєво полегшує цей процес у поза аудиторний час на основі реалізації персоналізованого підходу, 
дозволяє продуктивно організувати самостійну роботу з цієї навчальної дисципліни у ЗВО.

У процесі дослідно-експериментальної роботи було розроблено й приклади реалізації методу гейміфікації (групова форма) у процесі навчання студентів ЗВО англійської мови під час організації аудиторної роботи (практичні заняття).

1. Кооперативні або групові ігри (англ. co-operate/group games). Вони сприяють командній роботі, набуттю навичок розв'язання проблем i розвитку творчості. Студенти здобувають знання у процесі гри, підтримуючи один одного та вдосконалюючи навички володіння англійською мовою одночасно. Методичні поради для реалізації цієї форми гейміфікації такі: слухати один одного, виправляти помилки, аналізувати відповіді. На рис. 3 наведено приклад кооперативної гри, до якої можуть бути залучені всі студенти під час практичного заняття 3 англійської мови.

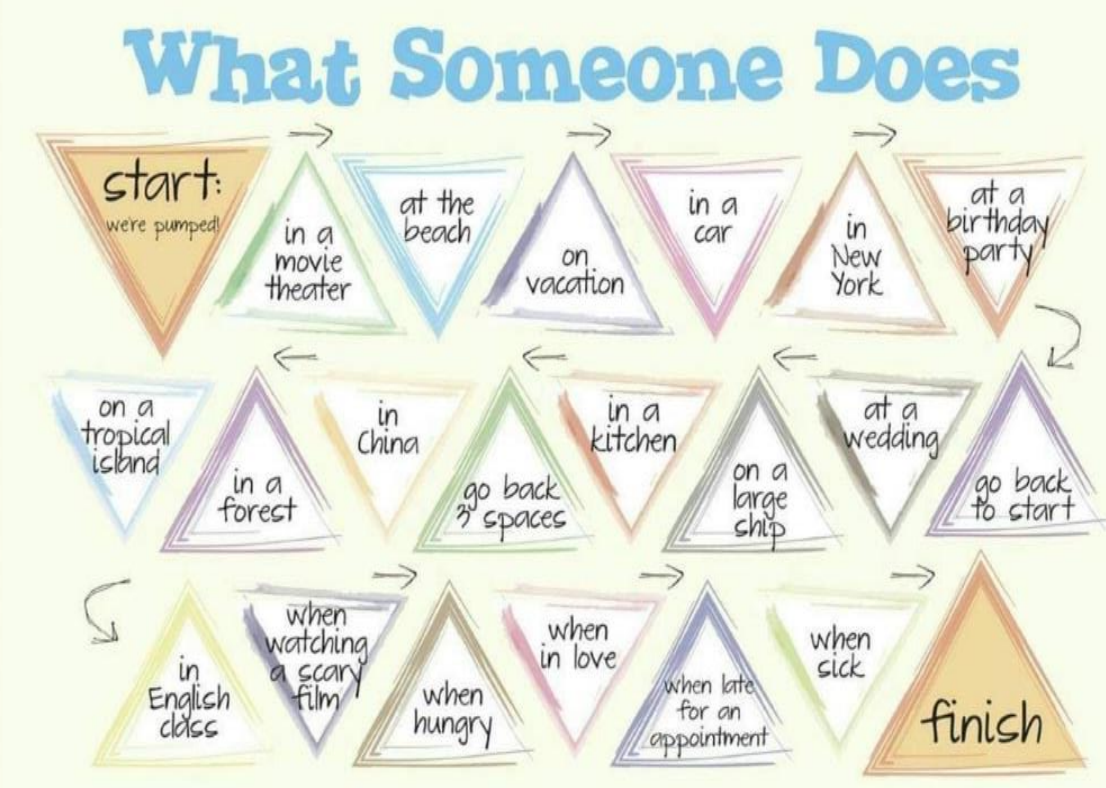

Рис. 3. Приклад кооперативної гри на заняттях з англійської мови у 3 ВО

2. Практика письма (англ. writing activity).

Студентам пропонується розглянути пропоновані малюнки або фрагменти відео, а потім написати коротеньку доповідь чи есе на тему того, що вони побачили або уявили. Реалізація цього методу передбачає такі методичні прийоми, як обговорення творів, дискусія, робота над 
помилками. Методичні поради: виправлення помилок під час письма або дискусії. Гейміфікація цього методу полягає у розподіленні ролей під час дискусії чи письмової роботи. Наприклад, умовно групу можна поділити на редакторів та виконавців замовлення, режисерів та глядачів, тощо.

3. Розширення словникового запасу та практика використання граматичних конструкцій (англ. vocabulary and grammar activity). Цей метод передбачає використання роздаткового матеріалу, а саме карток на запропоновані теми для спілкування, а також додаткових карток зі словами активної лексики професійного спрямування. Методичні поради: використання словника активної лексики, тлумачного словника тощо. Гейміфікація цього методу полягає у спробі учасників навчального процесу дати тлумачення в ігровій формі, по типу гри в «крокодила».

4. «Гра в акценти». Групі студентів пропонується написати коротеньку промову англійською мовою, а потім виголосити ії з акцентом будь-якої країни світу. Інші члени групи слухають, розпізнають вимову, порівнюючи їі зі зразками. У такий спосіб може бути організована робота над прислів'ями та приказками з англійської та української мови. При цьому відбувається вербальне порівняння та активна дискусія. Методичні поради: акцентування уваги на правильності вимови, поглиблення знань про культуру мовлення й розмаїття мов.

Висновки. Таким чином, результати проведеного дослідження підтверджують висновки зарубіжних учених (Alsawaeir, 2018; Bell, 2017; Bevins \& Howard, 2018; Dicheva, 2015; Faiella, 2015) про ефективність застосування методу гейміфікації в освітньому процесі вищої школи, зокрема у навчанні англійської мови. Використання методу гейміфікації сприяє підвищенню рівня володіння англійською мовою студентів, дозволяе реалізувати принципи доступності навчання, сприятливого емоційного фону, оптимізації навчального процесу (а саме добору завдань з урахуванням особливостей та потреб студентів), індивідуального підходу у навчанні, а також створює міцне підгрунтя для активізації пізнавальної діяльності й пізнавального інтересу студентів, самонавчання i саморозвитку, формування умінь працювати в команді, навичок комунікації та кооперації. Мотивація разом 3 ігровими механіками (правилами гри), інтерактивністю, зворотнім зв'язком та кооперативними завданнями створює інтерес до залучення в процес навчання, а також допомагає здобувачам освіти краще засвоїти та використовувати на практиці вміння володіння англійською мовою. 
Перспективи подальших розвідок полягають в експериментальній перевірці впливу методу гейміфікації (групова форма) на рівень навичок володіння і вмотивованості студентів до навчання англійської мови під час аудиторних (практичних) занять у ЗВО. 


\section{СПИСОК ЛІТЕРАТУРИ}

Комарницька, О. (2016) Особливості застосування мобільних технологій у навчанні. У: Новітні інформаційно-комунікаиійні технології в навчальному процесі: актуальні проблеми: матеріали Науково-методичної конферениії, 30 листопада 2016, Тернопіль (сс. 3-8). Тернопіль: ТОКІППО.

Ткаченко, О. (2015) Гейміфікація освіти: формальний i неформальний простір. Актуальні питання гуманітарних наук, 11, 303-309. Отримано 3: http://nbuv.gov.ua/UJRN/apgnd_2015_11_45.

Alsawaier, R. (2018). The Effect of Gamification on Motivation and Engagement, The International Journal of Information and Learning Technology, 35, (1), 56-79.

Bell, K. (2017). Game On!: Gamification, Gameful Design, and the Rise of the Gamer Educator. Baltimore: Johns Hopkins University Press.

Bevins, K. \& Howard, C. (2018). Game Mechanics and Why They Are Employed: What We know About Gamification So Far, Issues and Trends in Educational, 6(1), 1-21.

DeShutter, B. \& Abeele, V. (2014). Gradequest-Evaluating the Impact of Using Game Design Techniques in an Undergraduate Course. Fort Lauderdale: Foundation of Digital Games, Society for the Advancement of the Science of Digital Games.

Deterding, S., Dixon, D., Khaled, R., \& Nacke, L. (2011). From Game Design Elements to Gamefulness: Defining Gamification. In: Proceedings of the 15th International Academic MindTrek Conference: Envisioning Future Media Environments (pp. 9-15).

Dicheva, D. et al (2015). Gamification in Education: A Systematic Mapping Study, Journal of Educational Technology \& Society, 18(3), 75.

Faiella, F. \& Ricciardi, M. (2015). Gamification and Learning: A Review of Issues and Research, Journal of e-Learning and Knowledge Society, 11(3), 1-12.

Hamari, J., Koivisto, J. \& Sarsa, H. (2014). Does Gamification Work? A Literature Review of Empirical Studies on Gamification. Hawaii International Conference on System Sciences, 3025-3034.

Holman, C., Aguilar, S., \& Fishman, B. (2013). GradeCraft: What Can We Learn From a Game-inspired Learning Management System? Proceedings of the Third International Conference on Learning Analytics and Knowledge, 260-264.

Kim, A. J. (2000). Community building on the web: Secret strategies for successful online communities. Berkeley: Addison-Wesley Longman Publishing Co., Inc.

Kapp, K. M. (2012). The gamification of learning and instruction: game-based methods and strategies for training and education. Bloomsburg: John Wiley \& Sons.

Landers, R. N. \& Callan R. (2011). Casual Social Games as Serious Games: The Psychology of Gamification in Undergraduate Education and Employee Training. In: Serious Games and Edutainment Applications (pp. 399-423), Publisher: Springer, London.

Mak, H. W. (2013). The Gamification of College Lectures at the University of Michigan, Gamification Corporation, 8, 2-13.

Seaborn, K. \& Fels, D. (2015). Gamification in Theory and Action: A Survey, International Journal of Human-Computer Studies, 74, 14-31. 
Zichermann, G. \& Linder, J. (2010). Game-based marketing: inspire customer loyalty through rewards, challenges, and contests. New Jersey: John Wiley \& Sons.

\section{REFERENCES}

Komarnytska, O. (2016) Osoblyvosti zastosuvannia mobilnykh tekhnolohii u navchanni. [The application features of mobile technologies use in the process of studying]. Novitni informatsiino-komunikatsiini tekhnolohii v navchalnomu pro-tsesi: aktualni problemy: materialy Naukovo-metodychnoi konferentsii, 30 lystopada 2016, Ternopil [The latest information and communication technologies in learning: current issues: materials of scientific and methodological conference. 13.11.2016, Ternopil] (pp. 3-8). Ternopil : TOKIPPO.

Tkachenko, O. (2015) Heimifikatsiia osvity: formalnyi i neformalnyi prostir. [Gamification of education: formal and informal space]. Aktualni pytannia humanitarnykh nauk [Topical issues in the humanities], 11, 303-309. URL: http://nbuv.gov.ua/UJRN/apgnd_2015_11_45.

Alsawaier, R. (2018). The Effect of Gamification on Motivation and Engagement, The International Journal of Information and Learning Technology, 35, (1), 56-79.

Bell, K. (2017). Game On!: Gamification, Gameful Design, and the Rise of the Gamer Educator. Baltimore: Johns Hopkins University Press.

Bevins, K. \& Howard, C. (2018). Game Mechanics and Why They Are Employed: What We know About Gamification So Far, Issues and Trends in Educational, 6(1), 1-21.

DeShutter, B. \& Abeele, V. (2014). Gradequest-Evaluating the Impact of Using Game Design Techniques in an Undergraduate Course. Fort Lauderdale: Foundation of Digital Games, Society for the Advancement of the Science of Digital Games.

Deterding, S., Dixon, D., Khaled, R., \& Nacke, L. (2011). From Game Design Elements to Gamefulness: Defining Gamification. In: Proceedings of the 15th International Academic MindTrek Conference: Envisioning Future Media Environments (pp. 9-15).

Dicheva, D. et al (2015). Gamification in Education: A Systematic Mapping Study, Journal of Educational Technology \& Society, 18(3), 75.

Faiella, F. \& Ricciardi, M. (2015). Gamification and Learning: A Review of Issues and Research, Journal of e-Learning and Knowledge Society, 11(3), 1-12.

Hamari, J., Koivisto, J. \& Sarsa, H. (2014). Does Gamification Work? A Literature Review of Empirical Studies on Gamification. Hawaii International Conference on System Sciences, 3025-3034.

Holman, C., Aguilar, S., \& Fishman, B. (2013). GradeCraft: What Can We Learn From a Game-inspired Learning Management System? Proceedings of the Third International Conference on Learning Analytics and Knowledge, 260-264.

Kim, A. J. (2000). Community building on the web: Secret strategies for successful online communities. Berkeley: Addison-Wesley Longman Publishing Co., Inc.

Kapp, K. M. (2012). The gamification of learning and instruction: game-based methods and strategies for training and education. Bloomsburg: John Wiley \& Sons. 
Landers, R. N. \& Callan R. (2011). Casual Social Games as Serious Games: The Psychology of Gamification in Undergraduate Education and Employee Training. In: Serious Games and Edutainment Applications (pp. 399-423), Publisher: Springer, London.

Mak, H. W. (2013). The Gamification of College Lectures at the University of Michigan, Gamification Corporation, 8, 2-13.

Seaborn, K. \& Fels, D. (2015). Gamification in Theory and Action: A Survey, International Journal of Human-Computer Studies, 74, 14-31.

Zichermann, G. \& Linder, J. (2010). Game-based marketing: inspire customer loyalty through rewards, challenges, and contests. New Jersey: John Wiley \& Sons.

\section{Відомості про авторів}

Зеленська Людмила Дмитрівна

Доктор педагогічних наук, професор кафедри загальної педагогіки та педагогіки вищої школи Харківського національного педагогічного університету імені Г. С. Сковороди Каб. 315-В вул. Валентинівська, 2, Харків, Україна 61168 Тел. +38(096) 3520308 ORCID ID https://orcid.org/0000-0002-3324-5173 e-mail: zelenskaya_ludmila@ukr.net

\section{Ковінько Каріна Валеріївна}

Викладач кафедри англійської мови Харківського національного університету імені В.Н. Каразіна Каб. 10-10 пл. Свободи, 4, 61022 Харків, Україна, Тел. +38 (096) 0404037 ORCID ID

https://orcid.org/0000-0002-4082-9660 e-mail: kovinkokarina2010@gmail.com

\section{Zlenskaya Ludmila}

Doctor of Pedagogical Sciences, Associate Professor, Professor of

General Pedagogy and High School Pedagogy Department of H. S. Skovoroda Kharkiv National Pedagogical University Room 315-B, 2, Valentynivska Str, Kharkiv, Ukraine 61168 Tel. +38(096) 3520308 ORCID ID https://orcid.org/0000-0002-3324-5173 e-mail: zelenskaya_ludmila@ukr.net

\section{Kovinko Karina}

Lecturer of the English language department of V. N. Karazin Kharkiv National University Room 10-10, Svobody Square, 4, Kharkiv, Ukraine, 61022 Phone: +38 (096) 0404037 ORCID ID https://orcid.org/0000-0002-4082-9660 e-mail: kovinkokarina2010@gmail.com 